\title{
Raising Awareness of Urban and Suburban Hydric Resource Pollution in Promoting Urban Water Management in Northwest Uruguay
}

\author{
Elena Alvareda ${ }^{1}$, Franco Teixeira de Mello ${ }^{2}$, Gonzalo Sapriza ${ }^{1}$, Paola Russo ${ }^{1}$, Vanessa Erasun ${ }^{1}$, Pablo \\ Gamazo $^{1}$, Rogelio Texeira ${ }^{3}$, Adriana Piperno ${ }^{3}$ \\ ${ }^{1}$ Departamento del Agua, CENUR, Universidad de la República \\ Rivera 1350, Salto, Uruguay \\ alvareda@fq.edu.uy; frantei@fcien.edu.uy; adriana.piperno@gmail.com \\ ${ }^{2}$ Departamento de Ecología y Gestión Ambiental, CURE, Universidad de la República \\ Tacuarembó 20100, Maldonado, Uruguay \\ ${ }^{3}$ Facultad de Arquitectura, Diseño y Urbanismo, Universidad de la República \\ Br. Artigas 1031, Montevideo, Uruguay
}

\section{Extended Abstract}

In the last decades the increasing human population, urbanization and consumption rate, dramatically increased the pollutants and nutrients in the urban waters, changing the urban stream channel morphology, perturbing the ecosystem reducing the biotic richness, lead to the called "urban streams syndrome" [1]. Some researches put emphasis in urban impact and how to create efficient drainage systems for decrease industrial discharges and domestic wastewaters, sanitary sewer overflows problems, flow channelling and pipe systems for the urban stormwater runoff delivered to streams by hydraulically. All these issues are relevant to restore the streams in urban catchments and urban landscape. In this sense, some advances towards an integrated management of urban water resources was proposed in Uruguay [2].

Urban and suburban streams in Uruguay, as in case of the "Ceibal" in the North of Uruguay, have serious problems of pollution causing an important environmental impact, being a risk to human health. These problems have already been identified by the authorities of the Ministry of Environmental and the Universidad de la República (UdelaR) reporting a deterioration in the quality and quantity of water resources in Uruguay [3]. The quality of life in cities and towns have to be improve with coherent and sustainable approach to urban development policies. A decisive role in articulating the contributions of the different interdisciplinary stakeholder's academic, civil and governmental, dealing with these environmental problems, is carried out by the Water Urbans interdisciplinary Project from the UdelaR.

Firstly, identify the source of urban streams pollutants and the physical effects of urbanization [4], reducing discharges of wastewaters are the principally goals for restore and protect urban streams. Secondly, an adequate and efficient management of these natural resource is vital in order to meet the demands associated with population growth, environmental/ecological sustainability and adaptability to climate change in water systems [5].

In this work, we monitored some water physicochemical parameters, the stream flow and faecal coliforms in the "Ceibal", in an attempt to evaluate the cause-effect of the pollutants among the ecosystem related to the anthropogenic impact in an urban area with the aim to raise public and government awareness of the conformation of sustainable cities.

\section{References}

[1] C. J. Walsh, A. H. Roy, J. W. Feminella, P. D. Cottingham, P. M. Groffman, R. P. Morgan, "The urban stream syndrome: current knowledge and the search for a cure," J. N. Am. Benthol. Soc., vol. 24, no. 3, pp. 706-723, 2005.

[2] J. Alonso, A. Capandeguy, C. Chreties, A. Cuadrado, A. Gamarra, P. Guido, J. P. Martínez, N. Mazzeo, M. Mena, A. Piperno, F. Quintans, N. Rezzano, G. Sanguinet, P. Sierra, L. Silveira, J. Taks, "Aguas urbanas en Uruguay. Avances y desafíos hacia una gestión integrada," Ed. Piperno A., Quintans F., Conde D. Interamerican Network of Academies of Sciencies (IANAS). Press, 2015. [Online]. Available: http://unesdoc.unesco.org/images/0024/002452/245202s.pdf 
[3] MVOTMA, Uruguayan Housing, Land use planning and Environment Ministry., in Proceedings of the Second National Communications of the United Nations Framework Convention on Climate Change, pp. 44-46, 2004. [Online]. Available: http://www.cambioclimatico.gub.uy/images/stories/documentos/plan_nacional/proyectos_estrategicos/urync2.pdf

[4] J. P. Paul and J. L. Meyer, "Streams in the urban landscape," Annu. Rev. Ecol. Syst., vol. 32, pp. 333-65, 2001.

[5] P. Gleik, "The Changing Water Paradigm A Look at Twenty-first Century Water Resources Development," in IWRA, Water International, vol. 25, no 1, 127-137, 2000. 